\title{
Brexit's impact on Spanish media discourse: news coverage and audience reaction on Twitter
}

\author{
Luis-Miguel Pedrero-Esteban; Ana Pérez-Escoda; María-José Establés
}

Nota: Este artículo se puede leer en español en:

http://www.profesionaldelainformacion.com/contenidos/2021/nov/pedrero-perez-estables_es.pdf

How to cite this article:

Pedrero-Esteban, Luis-Miguel; Pérez-Escoda, Ana; Establés, María-José (2021). "Brexit's impact on Spanish media discourse: news coverage and audience reaction on Twitter". Profesional de la información, v. 30, n. 6, e300610.

https://doi.org/10.3145/epi.2021.nov.10

Manuscript received on $10^{\text {th }}$ May 2021 Accepted on $21^{\text {th }}$ July 2021

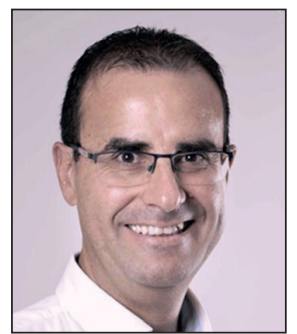

Luis-Miguel Pedrero-Esteban https://orcid.org/0000-0003-4949-2360

Universidad Antonio de Nebrija

Santa Cruz de Marcenado, 27

28015 Madrid, Spain

Ipedrero@nebrija.es

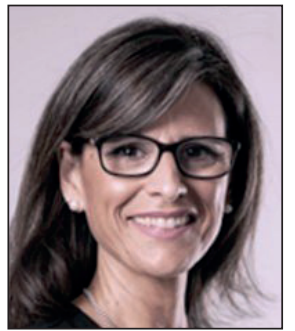

Ana Pérez-Escoda

https://orcid.org/0000-0002-4895-0043

Universidad Antonio de Nebrija

Santa Cruz de Marcenado, 27

28015 Madrid, Spain

aperezes@nebrija.es

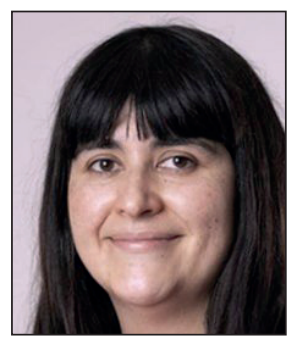

\author{
María-José Establés \\ https://orcid.org/0000-0001-9674-3981 \\ Universidad Antonio de Nebrija \\ Santa Cruz de Marcenado, 27 \\ 28015 Madrid, España \\ mestables@nebrija.es
}

\begin{abstract}
Social networks have become the transforming axes of communication and, therefore, extensions of journalistic activity. Although they are exposed to the dissemination of fake news and hoaxes that fuel tension and damage the health of democracy, they are also propitious spaces to legitimize the media in their responsibility to disseminate rigorous, truthful, and verified information. This research study analyzes the informative discourse on Twitter of the most relevant press, radio, and television outlets in Spain with respect to the formalization of Brexit, i.e., the definitive exit of the United Kingdom from the European Union. Based on a qualitative methodology, from a sample of 52,188 tweets, the 646 messages about this process, published between December 15, 2020, and January 15, 2021, categorized according to the tags and content distributed on this social network, are analyzed. The work allows the recognition of this discourse, to address its effects in the economic, political, educational, and sports areas. In general, negative language is identified when presenting the repercussions of the withdrawal of the United Kingdom from the EU, especially for Spain. Some media outlets show no interest in the international scope of the process and focus only on the national one. However, most of the messages on Brexit have a pro-European slant, albeit generating little social noise (mainly retweets), with the exception of some users concerned about issues related to the status of Gibraltar, racism, or stereotypes of tourists from the UK.
\end{abstract}

\section{Keywords}

Journalism; Social networks; Social media; Brexit; News coverage; Disinformation; Democracy; Communication; Media; Twitter.

\section{Funding}

This research study is part of the international project financed by the Horizon 2020 program "Mediatized discourses on Europeanization and their representations in public perceptions", Mediatized.eu. Grant agreement ID: 101004534, (H2020-SC6-Transformations-2020), funded by the European Commission, 01/01/2021 to 01/01/2023. 


\section{Introduction}

As a result of the digital, connected, and global context of the twenty-first century, interactions with communication media have become phenomena that have transformed social and political organizations, as well as the representation of knowledge (Bauman; Leoncini, 2018; Van-Dijck, 2016). The impact of social networks has resulted in a metamorphosis that has reshaped not only the information ecosystem but also the political and democratic discourse processes, which are now sustained on and split across the social networks, the new virtual agoras reaching a mass audience (Dader, 2020). The increase in the influence of these channels in the creation of social, political, and information discourses has increased citizens' concerns about fake news and misinformation: according to the Digital 2021 report by We are social, $56.4 \%$ of Internet users (4.66 billion people, almost $60 \%$ of the world's population) admitted being worried about their lack of certainty in the truthfulness of news on the Internet (Pérez-Escoda et al., 2021).

The worldwide explosion of the Covid-19 pandemic, and the advent of this disease without specific pharmacological treatments but exponentially growing infections, have underlined the value of digital media as disruptive scenarios for information, misinformation, polarization, fragmentation, and mediatization (Comisión Europea, 2018; Casero-Ripollés; García-Gordillo, 2020). Thus, traditional media, as drivers of the social communication narrative, which provides a discourse based on truthful information during crisis situations (Mayo-Cubero, 2020), have been joined by social networks, which have contributed to the creation of information that lies between "echo chambers" of public opinion or directed manipulations. Therefore, the democratization of social networks has become a fallacy of the unsettling aspects with respect to the freedoms of citizens (Pérez-Tornero, 2020), worthy of in-depth analysis. Thus, in the present case study, a systematized search is performed to identify the discourses of the main Spanish media on the Twitter social network during the implementation of a historic process: the complete exit of the United Kingdom from the European Union, baptized as Brexit as a combination of the terms Britain and exit (British Council, 2020).

The worldwide explosion of the Covid-19 pandemic, and the advent of this disease without specific pharmacological treatments but exponentially growing infections, have underlined the value of digital media as disruptive scenarios for information, misinformation, polarization, fragmentation, and mediatization

\section{Democracy, journalism, communication, and social networks}

To understand the context of this study, we must briefly describe the background and situation of a country such as Spain, subjected to four general elections between 2015 and 2019, together with the political conflict in Catalonia -the procés - which resulted in great political instability. The year 2016 also saw three events that strongly modified journalism and the power associated with communication changes mediated by social networks (Elías, 2018):

- firstly, the results of the referendum on the exit of the United Kingdom from Europe (Brexit);

- secondly, the victory of Donald Trump in the U.S. presidential elections;

- and finally, the signing of the peace accords in Colombia.

Beyond the political and social implications of each of these events, their relevance was multiplied by the effect of social networks, their impact, and the new political communication strategies that needed to be developed to differentiate truth from falsehood (Coromina; Padilla, 2018; Tuñón-Navarro; Oleart; Bouza-García, 2019).

This context, together with the worldwide coronavirus crisis, exacerbated the processes of disinformation and negatively influenced the degree of confidence of the Spanish citizens on institutions and media (Pérez-Escoda et al., 2021; CIS, 2020; Masip; Suau; Ruiz-Caballero, 2020). According to the Standard Eurobarometer 93 (European Commission, 2020), the least trusted institutions were the political parties, followed by the Spanish Government (Figure 1). These indicators have altered the political interest index, which strongly increased (more interest) in Ireland, Luxemburg, and Greece. In Spain, on the contrary, the interest decreased: it is the UE country with the greatest percentage (35\%) of individuals who declare not having "any interest" in politics.

In light of the climate of mistrust of the population, magnified by the "infodemia" which surged during the Covid-19 health crisis, communication media had to make great efforts to reach a population that was socially and politically worn-out. The global nature and reach of the social networks provided the media with the opportunity to reach audiences who had massively migrated towards virtual environments, where they found opportunities but also risks (Larrondo-Ureta; Peña-Fernández; Meso-Ayerdi, 2020). This phenomenon altered the nature of public and private communication, with its pinnacle reached when a brand becomes a verb (to google, to tweet, etc.) (Van-Dijck, 2016, p. 14). However, not all social networks share the same dynamics or achieve the same credibility when considering journalism and communication. From its creation as a microblogging site in 2006, Twitter has been closely associated with storytelling and the new narrative formats promoted by traditional media and the new digital ones, from both their official accounts and the journalists' private ones (Hermida, 2012; Barnard, 2014; Marcos-García; Alonso-Muñoz; López-Meri, 2021). 


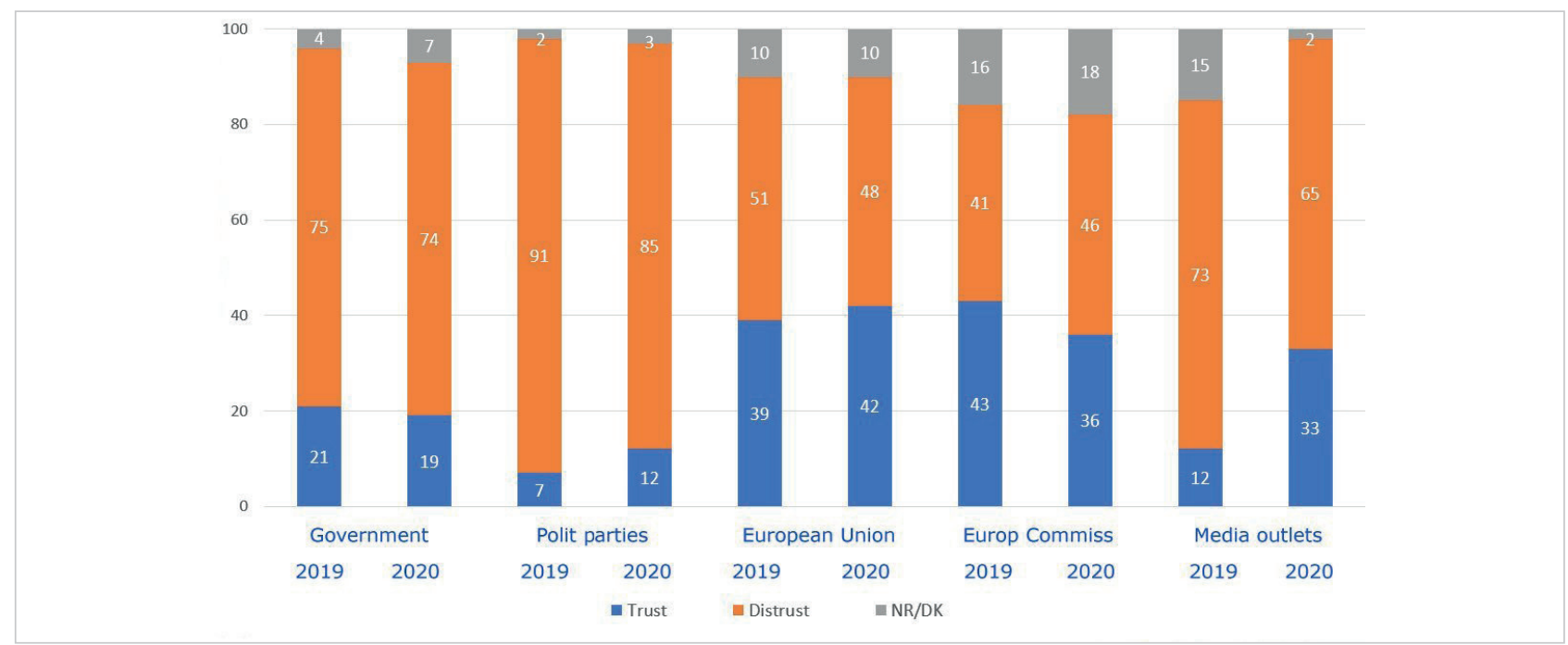

Figure 1. Percentage of confidence of the Spanish population towards political institutions and parties Source: Data from the Standard Eurobarometer 93 (European Commission, 2020)

The traditional pattern of the communicational-informational story has been enriched with other narratives and languages from digital environments that are able to reach vast sections of the population: social networks hoard a flow of communication that is parallel to the formal discourse of the (traditional) media, but reaching a greater number of users (Newman et al., 2020). Although Twitter was to become a multi-purpose public service, according to its founder Jack Dorsey, media companies promptly found an excellent "sounding board" in this network. It was ideal for creating a new type of journalism that was adapted to the characteristics of this platform: personalization, flexibility, immediacy, fragmentation, plurality (Brems et al., 2017; López-Rabadán; Mellado, 2019) and -the most interesting aspect- it provided them with the ability to have a direct effect on audiences that were fleeing from traditional media.

This phenomenon breaks away from the traditional communication studies, as it adds new agents to the media ecosystem. These agents, which are legitimized by the public in general and the digital context in particular, stand out due to their acceptance and their impact (Pérez-Curiel; Velasco-Molpeceres, 2020). Thus, despite their proven capacity to create and disseminate hoaxes and fake news -even more so in times of crisis (Brennen et al., 2020; Casero-Ripollés, 2020)-, and especially about political aspects (Haman; Školník, 2021; Marín-Dueñas; Simancas-González; Berzosa-Moreno, 2019), the inertia of this network's followers has been imposed, thus creating an unprecedented flow of information and communication.

It is precisely this context of communication change promoted by these networks, which corroborates one of the most important events in European politics: Brexit. The controversy surrounding Brexit, since the United Kingdom voted for its exit from the European Union in 2016, is highly relevant in the European sphere, which has suffered its first incident of division, after so many years spent on integration efforts and where the digital media played and are playing a fundamental role (Marquart et al., 2019; Krzyżanowski, 2019). The manner in which the British polls took place, and the role of the social networks with Cambridge Analytica in the background, make Brexit a historical event for different reasons, highlighting a political polarization and a murky use of the social networks with self-serving and questionable aims, as described and discussed in many research studies (Clarke; Goodwin; Whiteleye, 2017; Bastos; Mercea, 2018).

\section{Objectives}

Within this context of communication paradigm change, the processes of creation, distribution, and management of information have become adapted to a dystopian society overcome with information overload. Therefore to face "digital hyper-overcrowding" (Pérez-Tornero, 2020), it is necessary to understand how the media's communication discourses are produced -especially the informational ones- in social networks, to counteract disinformation and fake news. This research study is part of the international project financed by the European Horizon 2020 program 'Mediatized EU: Mediatized discourses on Europeanization and their representations in public perceptions' (Grant agreement ID: 101004534), whose objective is to study how information discourses are constructed in the media to promote or obstruct the European project, and how these are echoed in the public, starting with the triad of political elites, communication media, and audiences. The present work intends to examine the news and information discourses disseminated in the social network Twitter by the main Spanish communication media outlets, related to the final outcome of Brexit. Brexit is understood as

In light of the climate of mistrust of the population, magnified by the "infodemia" which surged during the Covid-19 health crisis, communication media had to make great efforts to reach a population that was socially and politically wornout 
the official exit of the United Kingdom from the European Union on January $1^{\text {st }}, 2021$, which puts an end to almost five years of European integration policies, thus defining it as a historical landmark. We are interested in answering the following research questions:

01. What types of messages were sent by the main Spanish communication media?

O2. Is there an 'anti-European' or 'pro-European' discourse about the subject of Brexit in the main Spanish communication media?

O3. What types of repercussions and reactions have been observed in the Spanish communication media audiences towards the messages received about Brexit?

\section{Methodology}

The present study utilized qualitative methods which include text-based data collection and analysis techniques, using text from the messages sent from the official accounts of the twenty-one most important communication media outlets in Spain with the greatest penetration in the press, radio, and television. The objective was to explore how these media treated the news on the definite exit of the United Kingdom from the European Union, and its repercussion on the audiences who consumed the news. For the collection and qualitative and quantitative content analysis of the data, the QSR Nvivo software was utilized. This analysis was conducted through the condensation of the meanings and the identification of categories according to the theoretical framework of the article and the research objectives defined, to reveal the different underlying discourse structures that are pro-European, or anti-European due to the exit of the United Kingdom from the European Union, at the economic, political, and social levels. Given the great number of tweets compiled, and to optimize the analysis of information, the QSR Nvivo software -which is commonly used in research studies in the areas of Social Sciences and Communication- facilitates the coding of not only the tweets, but the metadata that is part of the message as well.

More specifically, the research study co-authors analyzed the tweets and classified them into the different discourse categories to maximize neutrality in the treatment of the messages during the codification process, to promote the objectivity and validity of the results. To guarantee the reliability of the coders, the analysis criteria were agreed upon through meetings and work sessions, and the coding performed by each of the researchers were reviewed and adjusted according to the operational definitions of each category.

A total of three coding rounds were performed, which are detailed below. It should be taken into account that the first two sessions were centered on the tweets from the official accounts from the communication media outlets, while the third session focused on the repercussion of the tweets on the communication media audiences in Twitter.

Thus, the messages sent in the social network Twitter (Establés, 2020) about all the news items published about Brexit were analyzed. Once the tweets were collected, a first automated coding round was performed to discard all the messages that did not deal with any informational aspect associated with the exit of the United Kingdom from the European Union. Next, a second codification round was performed focused on other subjects associated to Brexit, such as news or themes related to this process that were detected through the hashtags inserted in the tweets from the official accounts of the communication media. In this second round, we also detected the retweets of some of the messages sent by official EU accounts, the British government, or journalists who were part of the staff of the communication media analyzed in this study.

\section{First codification round}

Automated codification with QSR Nvivo to discard messages that did not deal with Brexit-related news

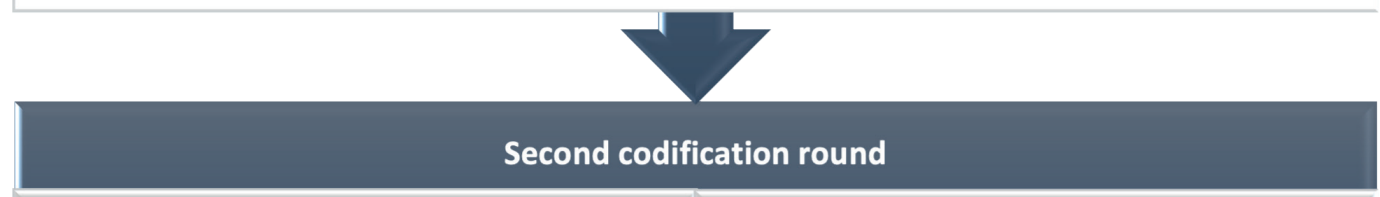

Analysis of hashtags and news related with the exit of the United Kingdom from the European Union
Sentiment analysis and opinion mining, nonsupervised (Nvivo), and supervised (manual analysis by the research team)

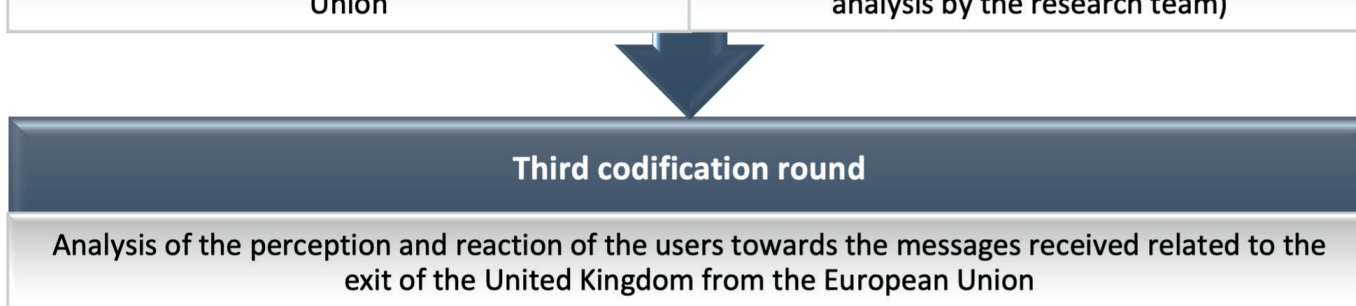

Figure 2. Development of the codification phases with QSR Nvivo 
Therefore, in the codification of the tweets phase, the \#Brexit tag was considered, although other hashtags that were greatly derived from this word were also taken into account (\#BrexitJELO, \#BrexitDay, \#BrexitDeal, etc.). During this phase, we considered sentiment analysis and opinion mining with natural language processing (Arcila-Calderón; Barbosa-Caro; Cabezuelo-Lorenzo, 2016), first in a non-supervised manner (Busón-Buesa, 2020), through the use of the QSR Nvivo software, and afterwards supervised by part of the research group.

After this second phase, a third codification round took place to understand the perception and reaction of the users towards the messages received related to the exit of the United Kingdom from the EU. Here, certain recurring themes were found, which were the most interesting to the Spanish audiences; among them we found the situation of the border between the British colony of Gibraltar and Spain, the difficulties of the Spanish truck drivers at the English Channel border, or the exports and imports of products between the European Union and Great Britain. Thus, sub-categories were added to the main category "Brexit" by condensing the meaning and identification of patterns, following the study's theoretical framework and the research questions, to find the discursive structures underlying the interaction of the users with the news published on the subject. Among these sub-categories, we mainly found clichés and stereotypes. All of the user accounts from which we obtained the tweets were anonymized to preserve the identity of the authors, although the accounts of the tweets from the media selected for the present study are shown. In the case of the users, we considered the level of interaction of their messages according to the classification according to the amount of text they produced, which is further described in section 5.3 of the present article.

\subsection{Study sample}

The sample selected for this research study is composed by the messages published in the social network Twitter by twenty-one communication media outlets in Spain and 42 Twitter accounts (general and specific, as shown in Table 3) between the second week of December, 2020, and the second week of January, 2021. This sample allowed us to analyze the discourses disseminated two weeks before the official exit date of the United Kingdom from the European Union ${ }^{2}$ (January $1^{\text {st }}, 2021$ ), as well as its repercussion in various Spanish communication media outlets 15 days after the start of the so-called Brexit.

The selection of the media outlets combines various criteria: the first is that the media outlets had to have verified profiles in Twitter: this social network was selected due to its great acceptance among social network users for commenting and sharing news. The second is its penetration in terms of audience (Barlovento, 2021) and its area of dissemination (countrywide). In the case of the radio stations, we evaluated the broadcaster's audience (AIMC, 2021) and their coverage at the national level. Lastly, in regard to the selection of traditional press and digital native press, we considered the evolution data of the audiences of the generalist newspapers, as well as their digital audiences, utilizing the data from Comscore.

Table 1. Communication media selected for the study

\begin{tabular}{|l|l|l|l|}
\hline \multicolumn{1}{|c|}{ Radio } & \multicolumn{1}{|c|}{ Television } & \multicolumn{1}{c|}{ Traditional press } & \multicolumn{1}{c|}{ Digital native press } \\
\hline & & ABC & El diario.es \\
Cadena SER & La 1 (TVE) & El mundo & Infolibre \\
Onda cero & Telecinco & El país & La marea \\
RNE & Antena 3 & La razón & OK diario \\
Cadena COPE & La sexta & El periódico & Voz populi \\
& & La vanguardia & 20 minutos.es \\
\end{tabular}

In total, the official Twitter accounts from twenty-one radio, television, traditional and digital native press media outlets were selected (Table 1). Nevertheless, and as many media outlets had other official profiles for international news (traditional press) or specific information programs (radio and television), the information on Brexit published in these profiles were also considered, as described in Table 2.

Table 2. Communication media with specific profiles in Twitter for international news and/or news programs

\begin{tabular}{|c|c|c|c|}
\hline Radio & Television & Traditional press & Digital native press \\
\hline $\begin{array}{l}\text { Herrera en COPE } \\
\text { Mediodía COPE } \\
\text { La tarde COPE } \\
\text { Hora } 25 \text { (Cadena SER) } \\
\text { Hoy por hoy (Cadena SER) } \\
\text { La ventana (Cadena SER) } \\
\text { La brújula (Onda cero } \\
\text { Más de uno (Onda cero) } \\
\text { Julia en la onda (Onda cero) } \\
\text { Noticias mediodía (Onda cero) } \\
\text { Las mañanas de RNE } \\
\text { Nunca es tarde (RNE) }\end{array}$ & $\begin{array}{l}\text { Antena } 3 \text { noticias } \\
\text { Informativos Telecinco } \\
\text { RTVE noticias } \\
\text { Telediarios TVE } \\
\text { La sexta noticias }\end{array}$ & $\begin{array}{l}\text { ABC internacional } \\
\text { El país internacional } \\
\text { El periódico internacional } \\
\text { El mundo internacional }\end{array}$ & $\begin{array}{l}\text { No specific profiles for } \\
\text { international news }\end{array}$ \\
\hline
\end{tabular}


Once the second codification round with QSR Nvivo of the tweets related with Brexit was performed, we determined how many of them, with a date of January $16^{\text {th }}$, 2021, were included in the sample. As shown in Table 3 , in the media with a specific profile in Twitter for international news, information programs or magazines, the number of tweets between their main accounts and the specific accounts, varied in the number of messages about the exit of the United Kingdom from the European Union. More specifically, the selection of all the specific accounts from radio and television programs was performed by following three criteria: 1 ) that they are active Twitter profiles, 2 that they are news-exclusive programs and/or magazines with news content, and 3 ) have repercussion in the share within their section in the time slot of the third wave of 2020 according to the General Media Study (AIMC, 2020).
The messages written by the Twitter users were not only centered on the definitive departure of the United Kingdom from the European Union, but on more local matters, such as the effect on the bilateral relationships between Spain and Gibraltar, the situation of the Spanish truck drivers, and the border controls between France and the UK, or how it would affect the Spanish Football League with respect to the signing of British players

Table 3. Twitter account data and number of tweets analyzed in the present study ${ }^{3}$.

\begin{tabular}{|c|c|c|c|c|c|c|}
\hline Type & Media & Twitter profile & Followers & $\begin{array}{c}\text { No tweets } \\
\text { Brexit }\end{array}$ & Specialized profile & $\begin{array}{c}\text { No tweets } \\
\text { Brexit }\end{array}$ \\
\hline \multirow{6}{*}{$\begin{array}{l}\text { Traditional } \\
\text { press }\end{array}$} & Elpaís & @el_pais & $7,982,644$ & 19 & @elpais_inter & 33 \\
\hline & Elmundo & @elmundoes & $3,895,826$ & 27 & @Elmundointer & 38 \\
\hline & $A B C$ & @abc_es & $2,097,635$ & 20 & @abc_mundo & 63 \\
\hline & La vanguardia & @LaVanguardia & $1,215,960$ & 18 & - & - \\
\hline & El periódico & @elperiodico & 690,577 & 20 & @EP_internac_cas & 1 \\
\hline & La razón & @larazon_es & 520,569 & 49 & - & - \\
\hline \multirow{7}{*}{$\begin{array}{l}\text { Digital native } \\
\text { press }\end{array}$} & El confidencial & @elconfidencial & 906,502 & 40 & - & - \\
\hline & El diario.es & @eldiarioes & $1,249,045$ & 39 & - & - \\
\hline & Infolibre & @_infoLibre & 326,315 & 1 & - & - \\
\hline & 20 minutos & @20m & $1,456,556$ & 4 & - & - \\
\hline & La marea & @lamarea_com & 229,438 & 0 & - & - \\
\hline & Voz populi & @voz_populi & 131,411 & 31 & - & - \\
\hline & OK diario & @okdiario & 331,439 & 22 & - & - \\
\hline \multirow{4}{*}{ Radio } & Cadena SER & @La_SER & $1,296,047$ & 16 & $\begin{array}{l}\text { @hora25 } \\
\text { @HoyPorHoy } \\
\text { @laventana }\end{array}$ & $\begin{array}{r}4 \\
12 \\
11\end{array}$ \\
\hline & Onda cero & @OndaCero_es & 562,416 & 7 & $\begin{array}{l}\text { @BrujulaOndaCero } \\
\text { @MasDeUno } \\
\text { @Juliaenlaonda } \\
\text { @MediodiaOC }\end{array}$ & $\begin{array}{r}7 \\
4 \\
13 \\
5\end{array}$ \\
\hline & COPE & $@ C O P E$ & 461,314 & 10 & $\begin{array}{l}\text { @HerreraenCOPE } \\
\text { @MediodiaCOPE } \\
\text { @LaTardeCOPE }\end{array}$ & $\begin{array}{l}5 \\
3 \\
0\end{array}$ \\
\hline & $R N E$ & @rne & 345,279 & 13 & @LasMananas_rne & 11 \\
\hline \multirow{4}{*}{ Television } & La 1 TVE & @La1_tve & 636,173 & 3 & $\begin{array}{l}\text { @rtvenoticias } \\
\text { @telediarios_tve }\end{array}$ & $\begin{array}{l}42 \\
22\end{array}$ \\
\hline & Antena 3 & @A3Noticias & $1,964,080$ & 1 & @A3Noticias & 10 \\
\hline & La sexta & @laSextaTv & $1,169,821$ & 8 & @sextaNoticias & 7 \\
\hline & Tele 5 & @telecincoes & $1,691,715$ & 2 & @informativost5 & 5 \\
\hline
\end{tabular}

Likewise, as shown in Table 3, at total of 646 tweets in Spanish ${ }^{4}$ were analyzed, in which we found news published in the Spanish media about Brexit, from a total of 52,188 tweets published by the selected accounts during the period analyzed (as observed in Table 4). Of these tweets, a total of 350 were published in the main Twitter accounts of these media, while 296 tweets were published in the media's specific accounts for international news, information and/or magazines As the present work deals with a case study of the impact of Brexit on the news published by Spanish communication media in their Twitter profiles, an analysis was conducted of the total percentage of coverage of these messages over the total number of tweets published. More specifically, Table 4 shows the repercussion of the general Twitter profiles of the communication media selected for this study, while Table 5 shows the specialized Twitter profiles from these communication media. 
Table 4. Generic Twitter profiles of the communication media selected for this study.

\begin{tabular}{|c|c|c|c|c|c|}
\hline Type & Media & Twitter profile & $\begin{array}{c}\text { Number tweets be- } \\
\text { tween } 12 / 15 / 20 \text { and } \\
1 / 15 / 21\end{array}$ & $\begin{array}{c}\text { Number Brexit } \\
\text { tweets }\end{array}$ & $\begin{array}{l}\% \text { tweets about Brexit } \\
\text { from the total published } \\
\text { in the period analyzed }\end{array}$ \\
\hline \multirow{6}{*}{$\begin{array}{l}\text { Traditional } \\
\text { press }\end{array}$} & Elpaís & @el_pais & 3,151 & 19 & 0.60 \\
\hline & El mundo & @elmundoes & 3,090 & 27 & 0.87 \\
\hline & $A B C$ & @abc_es & 2,812 & 20 & 0.59 \\
\hline & La vanguardia & @LaVanguardia & 3,028 & 18 & 0.59 \\
\hline & El periódico & @elperiodico & 3,140 & 20 & 0.63 \\
\hline & La razón & @larazon_es & 3,099 & 49 & 1.58 \\
\hline \multirow{7}{*}{$\begin{array}{l}\text { Digital native } \\
\text { press }\end{array}$} & El confidencial & @elconfidencial & 2,697 & 40 & 1.48 \\
\hline & El diario.es & @eldiarioes & 3,063 & 39 & 1.27 \\
\hline & Infolibre & @_infoLibre & 1,378 & 1 & 0.07 \\
\hline & 20 minutos & @20m & 2,892 & 4 & 0.13 \\
\hline & Lamarea & @lamarea_com & 1,234 & 0 & 0 \\
\hline & Voz populi & @voz_populi & 2,756 & 31 & 1.12 \\
\hline & OK diario & @okdiario & 3,141 & 22 & 0.70 \\
\hline \multirow{4}{*}{ Radio } & Cadena SER & @La_SER & 3,048 & 16 & 0.52 \\
\hline & Onda cero & @OndaCero_es & 1,262 & 7 & 0.55 \\
\hline & COPE & @COPE & 3,077 & 10 & 0.32 \\
\hline & $R N E$ & @rne & 1,139 & 13 & 1.14 \\
\hline \multirow{4}{*}{ Television } & La 1 TVE & @La1_tve & 1,101 & 3 & 0.27 \\
\hline & Antena 3 & @A3Noticias & 2,683 & 1 & 0.03 \\
\hline & La sexta & @laSextaTv & 2,854 & 8 & 0.28 \\
\hline & Tele 5 & @telecincoes & 1,543 & 2 & 0.13 \\
\hline
\end{tabular}

Table 5. Specialized Twitter profiles belonging to the communication media selected for the present study.

\begin{tabular}{|c|c|c|c|c|c|}
\hline Type & Media & Specialized profile & $\begin{array}{c}\text { Number tweets be- } \\
\text { tween } 12 / 15 / 20 \text { and } \\
1 / 15 / 21\end{array}$ & $\begin{array}{c}\text { Number Brexit } \\
\text { tweets }\end{array}$ & $\%$ tweets about Brexit \\
\hline \multirow{6}{*}{$\begin{array}{l}\text { Traditional } \\
\text { press }\end{array}$} & Elpaís & @elpais_inter & 368 & 33 & 8.96 \\
\hline & El mundo & @Elmundointer & 298 & 38 & 12.75 \\
\hline & $A B C$ & @abc_mundo & 435 & 63 & 14.48 \\
\hline & La vanguardia & - & --- & - & - \\
\hline & El periódico & @EP_internac_cas & 1 & 1 & 100 \\
\hline & La razón & - & - & - & -- \\
\hline \multirow{7}{*}{$\begin{array}{l}\text { Digital native } \\
\text { press }\end{array}$} & El confidencial & - & - & - & - \\
\hline & El diario.es & - & - & - & - \\
\hline & Infolibre & - & - & - & - \\
\hline & 20 minutos & - & - & - & - \\
\hline & La marea & - & - & - & - \\
\hline & Voz populi & - & - & - & - \\
\hline & OK diario & - & - & - & - \\
\hline \multirow{4}{*}{ Radio } & Cadena SER & $\begin{array}{l}\text { @hora25 } \\
\text { @HoyPorHoy } \\
\text { @laventana }\end{array}$ & $\begin{array}{l}541 \\
788 \\
322\end{array}$ & $\begin{array}{c}4 \\
12 \\
11\end{array}$ & $\begin{array}{l}0.74 \\
1.52 \\
3.42\end{array}$ \\
\hline & Onda cero & $\begin{array}{l}\text { @BrujulaOndaCero } \\
\text { @MasDeUno } \\
\text { @Juliaenlaonda } \\
\text { @MediodiaOC }\end{array}$ & $\begin{array}{c}574 \\
692 \\
1,059 \\
215\end{array}$ & $\begin{array}{c}7 \\
4 \\
13 \\
5\end{array}$ & $\begin{array}{l}1.22 \\
0.58 \\
1.23 \\
2.32\end{array}$ \\
\hline & COPE & $\begin{array}{l}\text { @HerreraenCOPE } \\
\text { @MediodiaCOPE } \\
\text { @LaTardeCOPE }\end{array}$ & $\begin{array}{c}929 \\
82 \\
386 \\
\end{array}$ & $\begin{array}{l}5 \\
3 \\
0\end{array}$ & $\begin{array}{c}0.54 \\
3.66 \\
0\end{array}$ \\
\hline & $R N E$ & @LasMananas_rne & 211 & 11 & 5.21 \\
\hline \multirow{4}{*}{ Television } & La $1 T V E$ & $\begin{array}{l}\text { @rtvenoticias } \\
\text { @telediarios_tve }\end{array}$ & $\begin{array}{l}3,120 \\
1,311\end{array}$ & $\begin{array}{l}42 \\
22\end{array}$ & $\begin{array}{l}1.34 \\
1.67 \\
\end{array}$ \\
\hline & Antena 3 & @A3Noticias & 2,356 & 10 & 0.42 \\
\hline & La sexta & @sextaNoticias & 2,483 & 7 & 0.28 \\
\hline & Tele 5 & @informativost5 & 1,863 & 5 & 0.27 \\
\hline
\end{tabular}




\section{Results}

Since the referendum on the exit of the United Kingdom as a member state of the European Union on June $23^{\text {rd }}$, 2016, and until it came into force on January $1^{\text {st }}, 2021$, Brexit had had a great international repercussion. In the case of the main Spanish communication media, sporadic information was provided in the different communication spaces to describe the negotiations and terms with which the exit took place. The present study has focused on the coverage dedicated to the end of the process; according to the objectives described above, the results are presented in four different phases:

1. Types of messages and discourses about the formalization of Brexit found in Twitter published by the Spanish media outlets a as set;

2. Types of messages and discourses about the formalization of Brexit in each of the media outlets analyzed;

3. Tags or hashtags linked to the formalization of Brexit;

4. Interaction of the Twitter users and the communication media, in relation to the news published about Brexit.

\subsection{Types of messages and discourses detected about Brexit}

The period selected for this study -December 15th, 2020, to January 15th, 2021-, is marked by varying information about different political, cultural, social, sport and economic areas that affected the EU members as well as the United Kingdom. Nevertheless, two differentiated phases exist when addressing the news: the first encompasses the period until December $30^{\text {th }}, 2020$, and the second from December $31^{\text {st }}, 2020$, to January $15^{\text {th }}, 2021$. This temporal differentiation is due to the last details which needed to be negotiated between the highest levels of the EU and the United Kingdom government ${ }^{5}$ before the official exit on January $1^{\text {st }}, 2021$.

Likewise, the type of discourses that were disseminated by the communication media analyzed is noteworthy. As pointed out in the second round of codification, sentiment analysis and opinion mining was performed. For this, a differentiation was made between the messages that utilized a more negative language about the subject (how the United Kingdom's exit affects the European and/or Spanish interests), and more positive language. It should be highlighted that the tweets that dealt with this matter were also the headlines used by the communication media to present the news item they referred to, and this data helped us to infer what the editorial line was of each of the

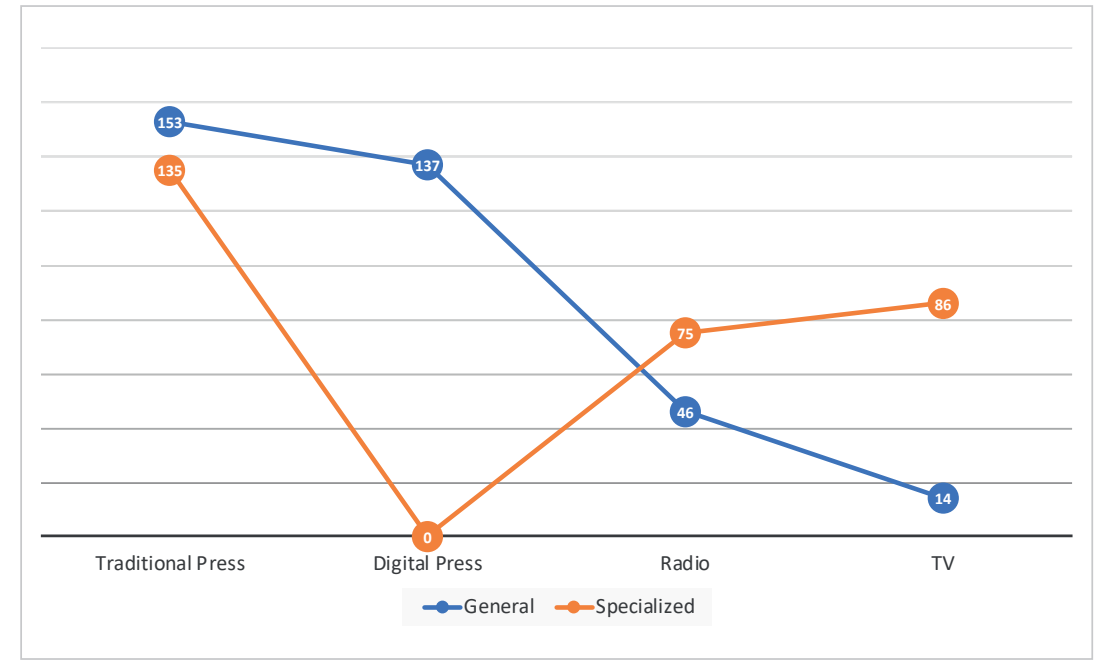

Figure 3. Number of tweets about Brexit in each communication media outlet $(12 / 15 / 2020$ to 01/15/2021). media outlets with respect to Brexit.

Therefore, we can observe that in the 646 tweets analyzed, $55.36 \%$ used a moderately negative to very negative language about the effects of Brexit on the European Union and/or Spain, as compared to $44.64 \%$ which used a discourse that was moderately to very positive. As shown in Table 6, of these negative discourses, $27.68 \%$ of the tweets were "negative", $25 \%$ were "moderately negative", and 22.32\% were "positive". Some examples of "negative", "moderately negative", and "positive" are the following:

- Example of a tweet with a negative discourse: El gran atraco del Brexit (The great Brexit heist) https://t.co/gEQLwfAlkO @elconfidencial, 10-1-2021.

- Example of a tweet with a moderately negative discourse: VÍDEO I Ya empieza a haber problemas para volar entre Reino Unido y España por el Brexit (Problems have started to appear for flying between the United Kingdom and Spain due to Brexit) https://t. co/6PhWhqbHzY@A3Noticias, 3-1-2021.

- Example of a tweet with a positive discourse: @InformeSemanal empieza el año abordando el Brexit y las consecuencias de la
Table 6. Analysis of the types of discourses in Twitter of the media selected

\begin{tabular}{|l|c|}
\hline \multicolumn{1}{|c|}{ Tipo } & $\%$ \\
\hline 1. Moderately negative & 25.00 \\
\hline 2. Negative & 27.68 \\
\hline 3. Very negative & 2.68 \\
\hline 4. Moderately positive & 18.30 \\
\hline 5. Positive & 22.32 \\
\hline 6. Very positive & 4.02 \\
\hline
\end{tabular}


pandemia en el urbanismo con: "Brexit, la nueva frontera" "Cuando las ciudades sanan" (@InformeSemanal begins the year addressing Brexit and the consequences of the pandemic on urbanism with: "Brexit, the new frontier" "When cities heal") https://t.co/krsE3ZDigR https://t.co/pj2SZmh4lz @La1_tve, 2-1-2021.

Specifically, the main categories detected in the qualitative content analysis of the tweets were the following: politics, economy, and society. In the next level, the subcategories of the messages detected were codified in the following manner:

- Politics: legislation, diplomacy, borders.

- Economy: tourism, European Union financing, EU aids and subsidies, taxes, customs.

- Society: education, health, sports, research, leisure and entertainment, cultural stereotypes.

With that in mind, some of the subjects that had an effect on the news published in Twitter by the Spanish communication media studied were the following: the controversies between the British Prime Minister, Boris Johnson, and other European leaders, the status of Gibraltar, the border between Northern Ireland and the Republic of Ireland, the vaccines and quarantines against Covid-19, the status of the British and European football players in the different football leagues, the issuing of passports or the exit of the United Kingdom from the Erasmus program, among other matters of interest for the media.

\subsection{Types of messages and discourses detected in each medium}

When delving into the nature of the communication media analyzed, substantial differences were observed between them when sharing the news related to Brexit in Twitter. Specifically, three important results emerged:

- The type of coverage of the communication media, mainly if it is within a national or regional area, has an influence when dealing with this type of information in Twitter.

- If the media outlet has an interest in international news for their publication in social networks; for example, if it has a specific international news Twitter profile.

- The ideology or editorial line of each medium, which has an influence on the construction of messages with a greater or lesser pro-European meaning.

- The interaction generated with the information coverage.

As the present study focused on Spanish communication media, the news limited to the domestic sphere had a greater weight than those which referred to other countries, including those that were part of the European Union. Nevertheless, if we consider the different types of media -written press, digital native press, radio and television- we found that in the case of the written press, the news about Brexit had a greater impact on the specific Twitter accounts dedicated to international news (Figure 4). We also saw other notable differences between the Twitter accounts from the different media outlets studied.

An inertia that was opposite the press was found in the radio (Figure $5)$, as the generic accounts -@La_ SER; @COPE; @rne-published more informative messages as compared to the specific account; although in the case of @OndaCero_es, the

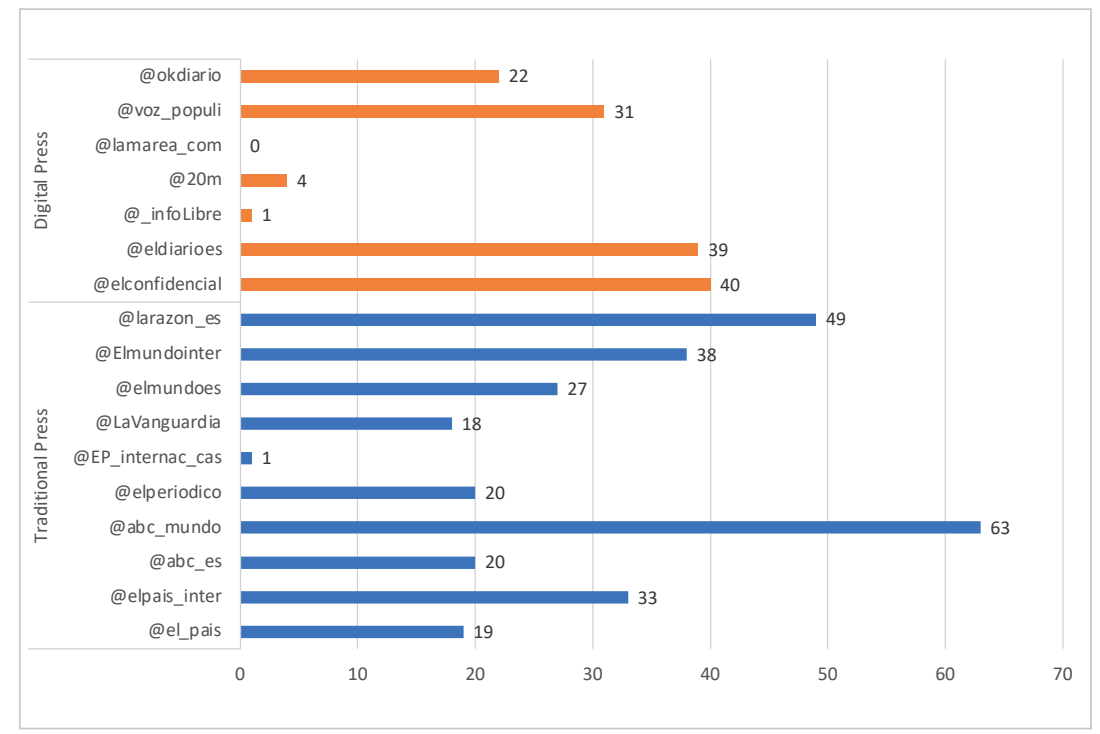

Figure 4. Brexit-related tweets in the traditional and native press $(12 / 15 / 2020$ to $01 / 15 / 2021)$.

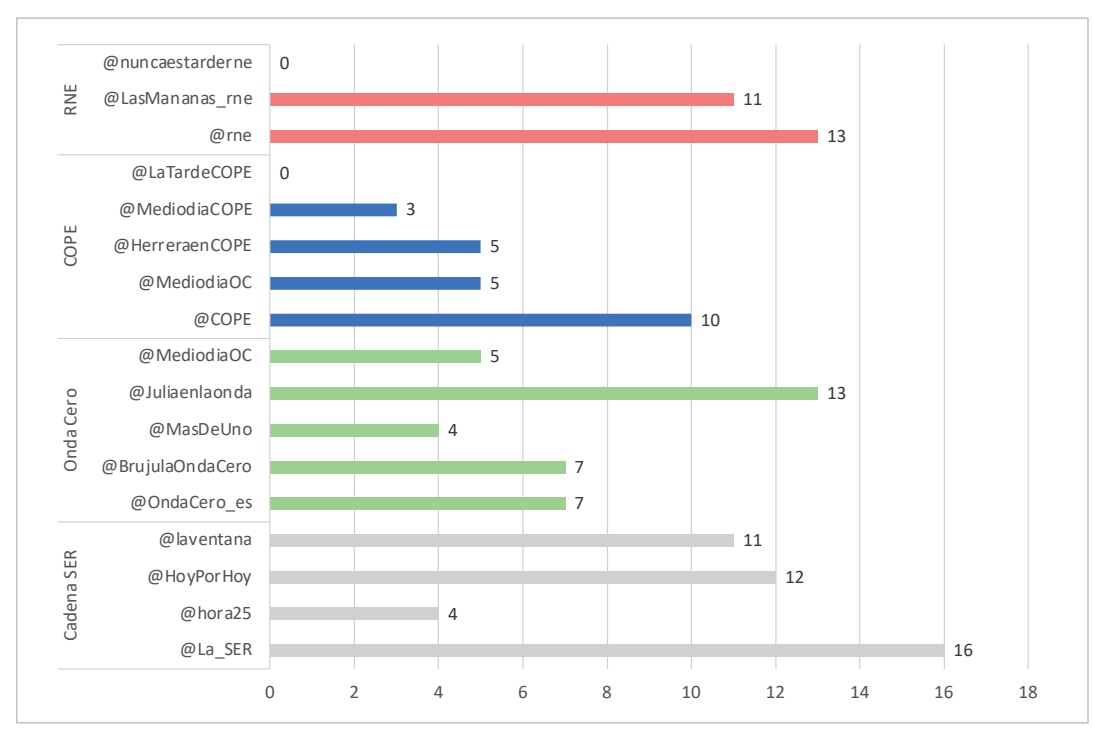

Figure 5. Tweets on Brexit from the radio outlets (12/15/2020 to 01/15/2021) 


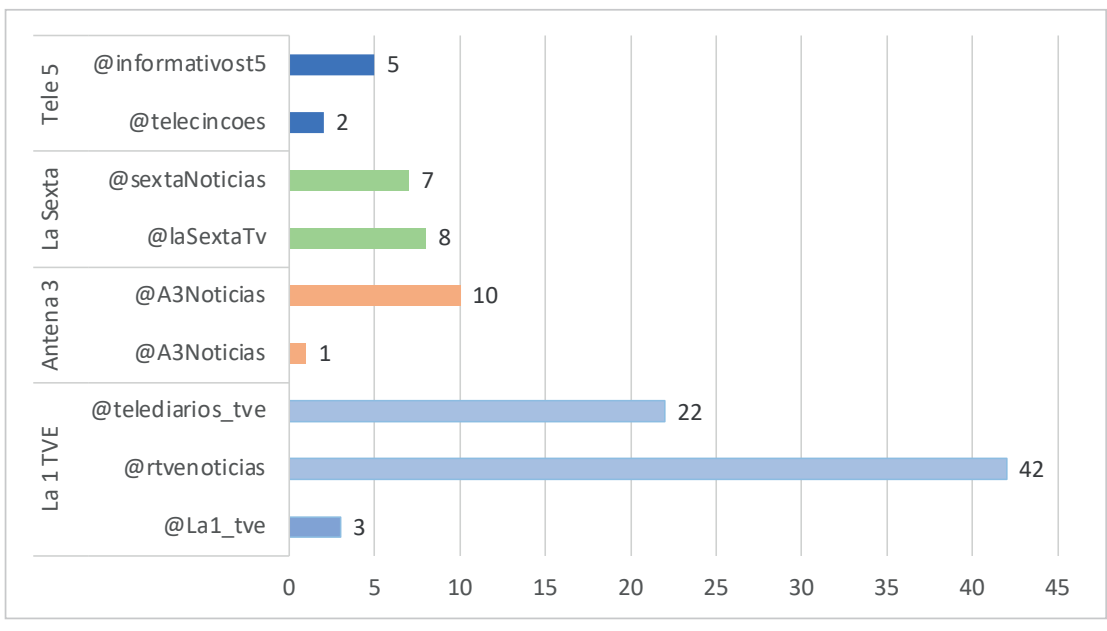

Figure 6. Tweets on Brexit in television media outlets (12/15/2020 to 01/15/2021)

publications related to Brexit were smaller in number than in one of its specific accounts, @ Juliaenlaonda. And as a whole, the accounts associated with @La_SER offered the greatest amount of news coverage in Twitter during the period studied.

Lastly, Figure 6 shows how the television media resolved the news coverage about Brexit in Twitter; the activity of the accounts belonging to the public entity RTVE is highlighted above the others.

As for the interaction created by the news coverage about Brexit in the media, some examples should be highlighted (due to space limitations, we cannot explain all of them): in the specific account for international news of the $A B C$ newspaper, we detected a greater number of tweets about Brexit (63) than in the generic account (20), although there was a greater dissemination and interaction with the tweets sent from the main profile (@abc_es, Figure 8), than from the @abc_mundo (abc_world) profile (Figure 7).

In the area of digital native press, some media outlets that were more specialized on social content -for example $L a$ Marea or Infolibre- did not echo the information about Brexit in their corresponding profiles in Twitter, except as testi-

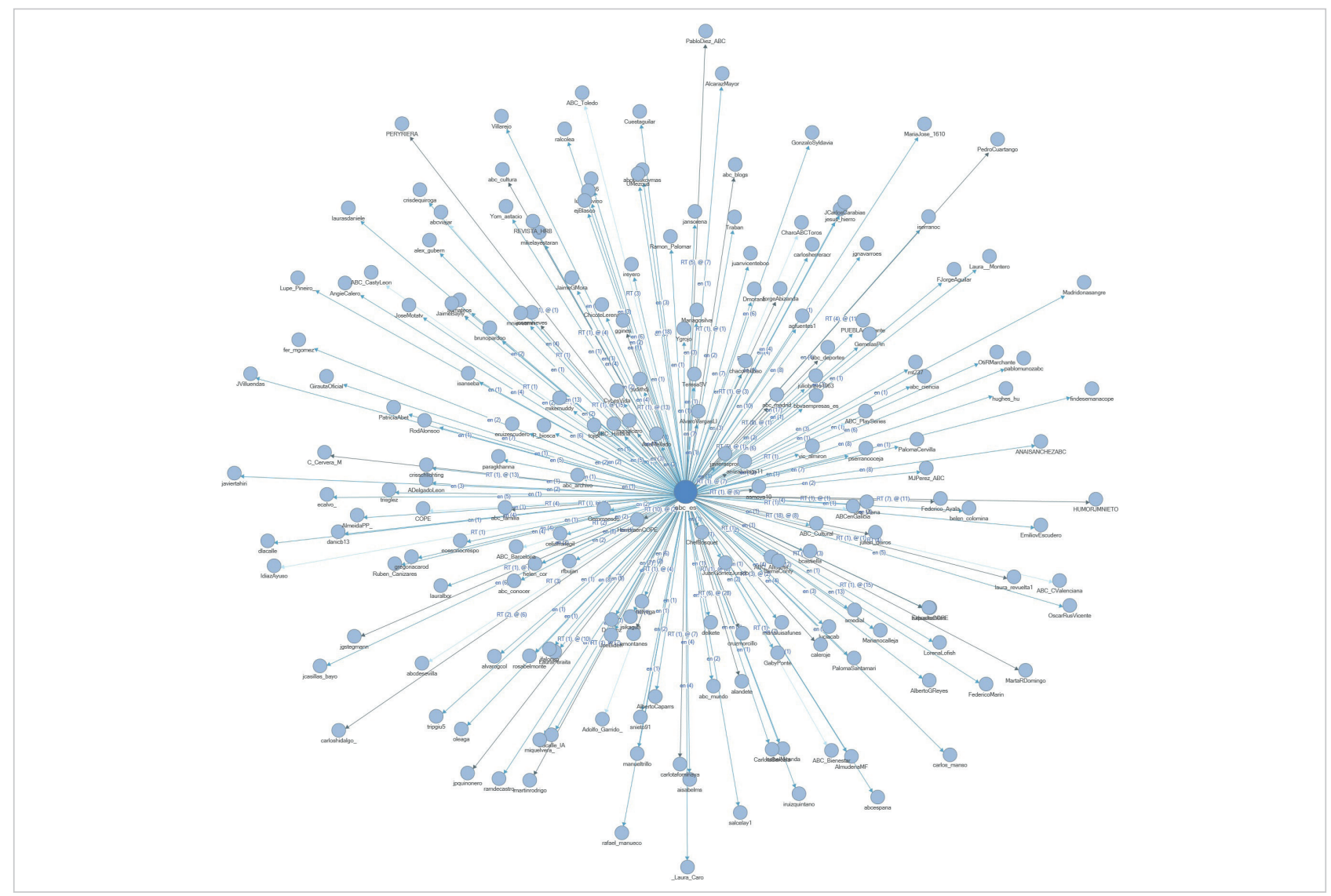

Figure 8. Retweets (RT) and comments (en) between Twitter profiles with the @abc.es account 


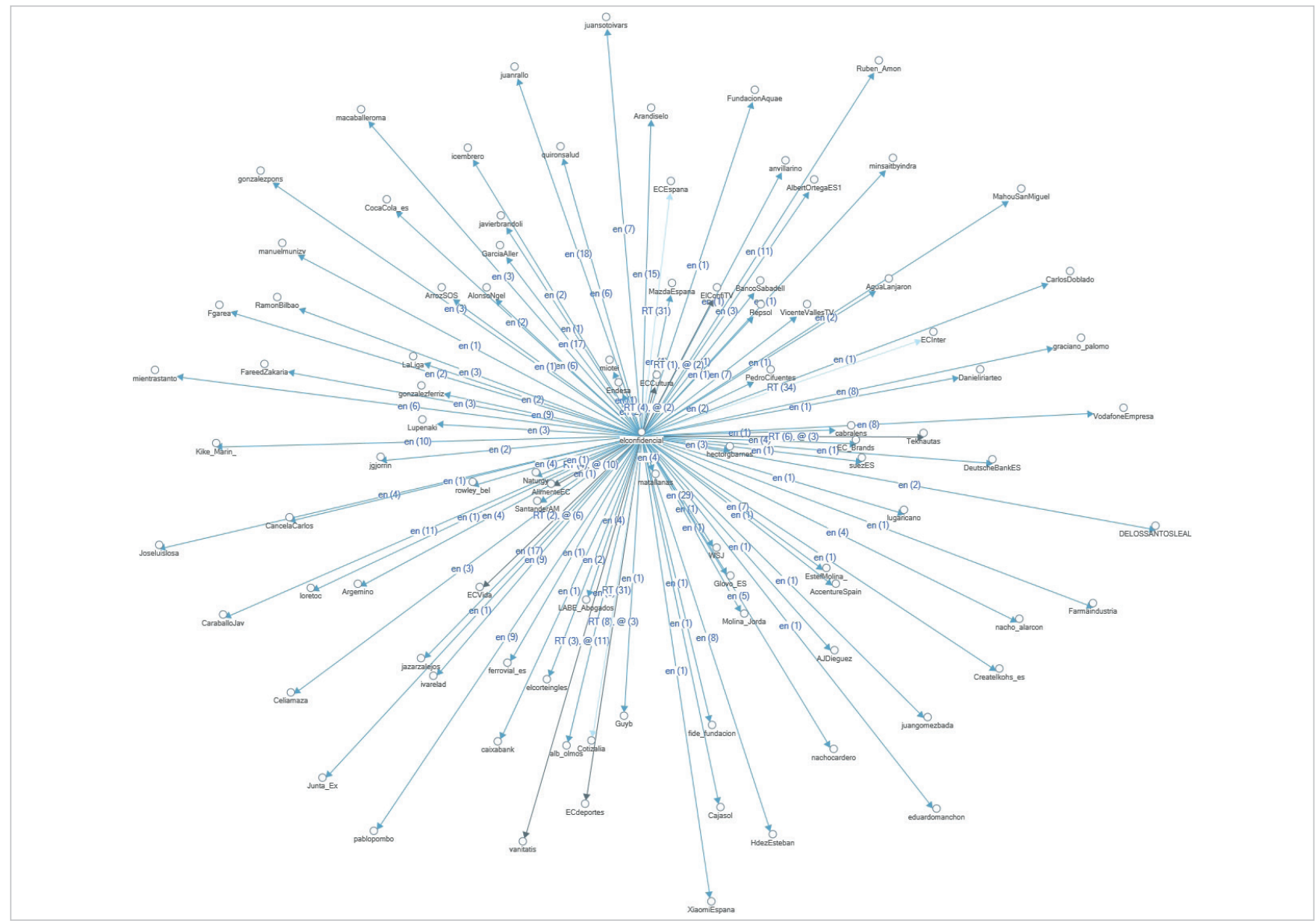

Figure 9. Retweets (RT) and comments (en) in the @elconfidencial Twitter account

monies. In turn, the digital media that were ideologically leaning towards the conservative political spectrum, such as $O K$ diario, did pay attention to this process, although they disseminated discourses that were less pro-European. The digital native press outlet that most disseminated opinion articles, reports, and news in its Twitter profile, was El confidencial (Figure 9).

With respect to the radio broadcasters, the trend found in the specific Twitter accounts about international news was true for Radio Nacional de España, Onda Cero, and Cadena SER, but not for Cadena COPE. The generic Twitter profile of the latter had a greater number of followers, and therefore, a greater impact, as shown in Table 3 . This could imply that the strategy utilized by this social network is to provide more coverage to this type of news from this generic profile, as opposed to the specific ones. Nevertheless, one of the star programs in this radio station, Herrera en COPE, who also had a Twitter account, was very active in providing information about the exit of the United Kingdom from the European Union (Figure 10).

Lastly, in the four television channels analyzed -La 1, Antena 3, Telecinco and La sexta-a smaller impact of the Brexit-related news was detected on the generalist profiles, with this type of content moved to the specific Twitter accounts. One of the channels which granted more importance to the news related to the exit of the United Kingdom from the European Union was the news program "Informativos" from TVE (Figure 11).

\subsection{Interaction of users and media with Brexit news in Twitter}

It is important to highlight that the exit of the United Kingdom from the European Union was not very interesting for the more active users of the official Twitter profiles of the communication media. In the present study, various types of profiles were active users, from the lowest level of interaction, to another more advanced one according to the taxonomy of users/fans systematized by Establés (2019) and Establés, Guerrero-Picó and Contreras-Espinosa (2020). More specifically, the following categories were utilized: talk-show participants and occasional content creators (aspirational users, collaborators, and pro-ams) ${ }^{6}$. It was found that most of the contents were dedicated, in order of importance, to retweets of the messages"; "likes", or commenting on some published news items.

Table 8 shows the number of Twitter users categorized as "talk-show" and/or "content creators", who interacted with the published news about Brexit from Spanish communication media in Twitter. Specifically, we found that $86.35 \%$ of the interactions were from talk-show hosts/participants, while $13.65 \%$ were conducted by Twitter users defined as "content creators", given that they had broadcasted some message in which they provided an added value, such as links to news 


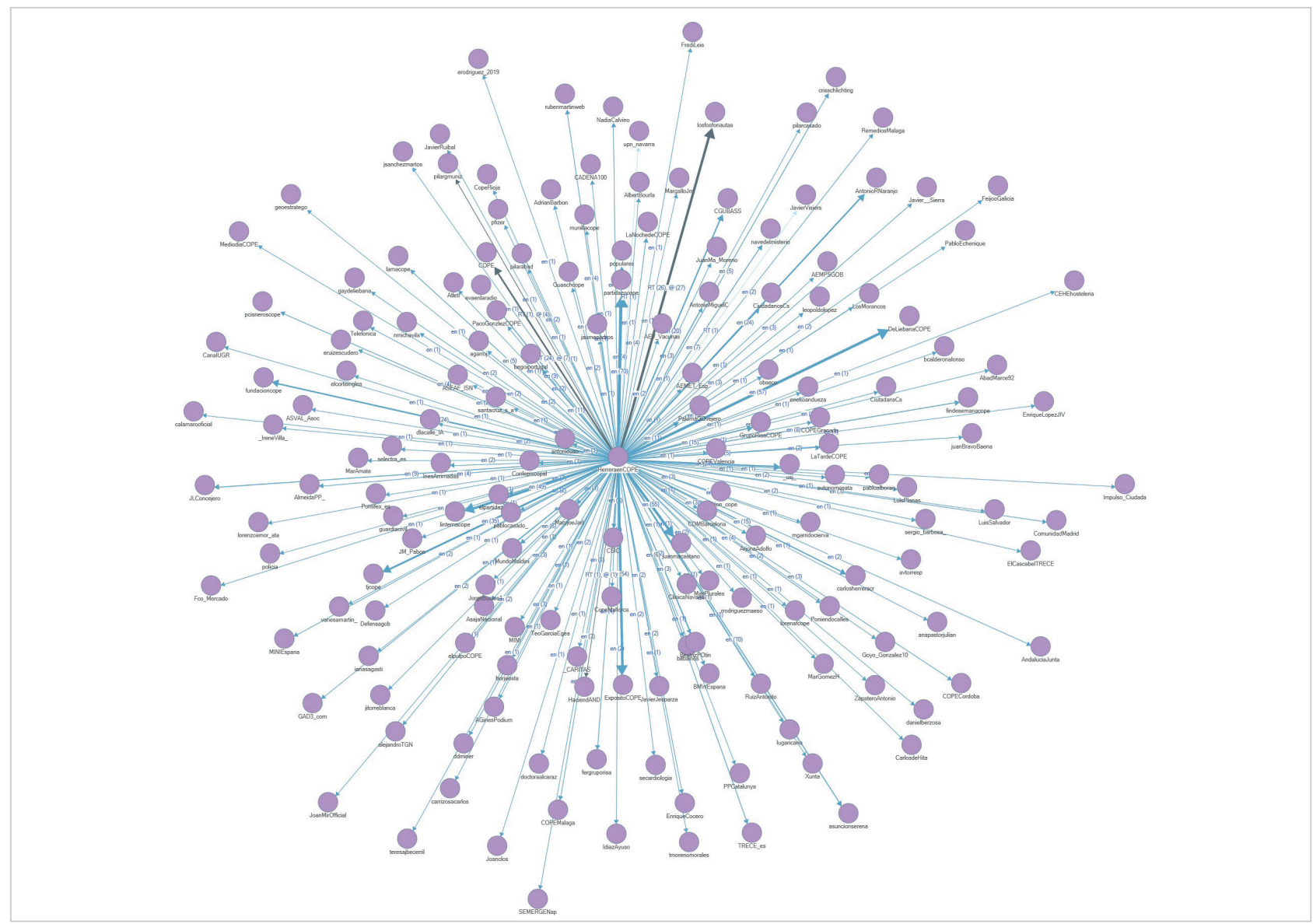

Figure 10. Retweets (RT) and comments (en) in Twitter from the @

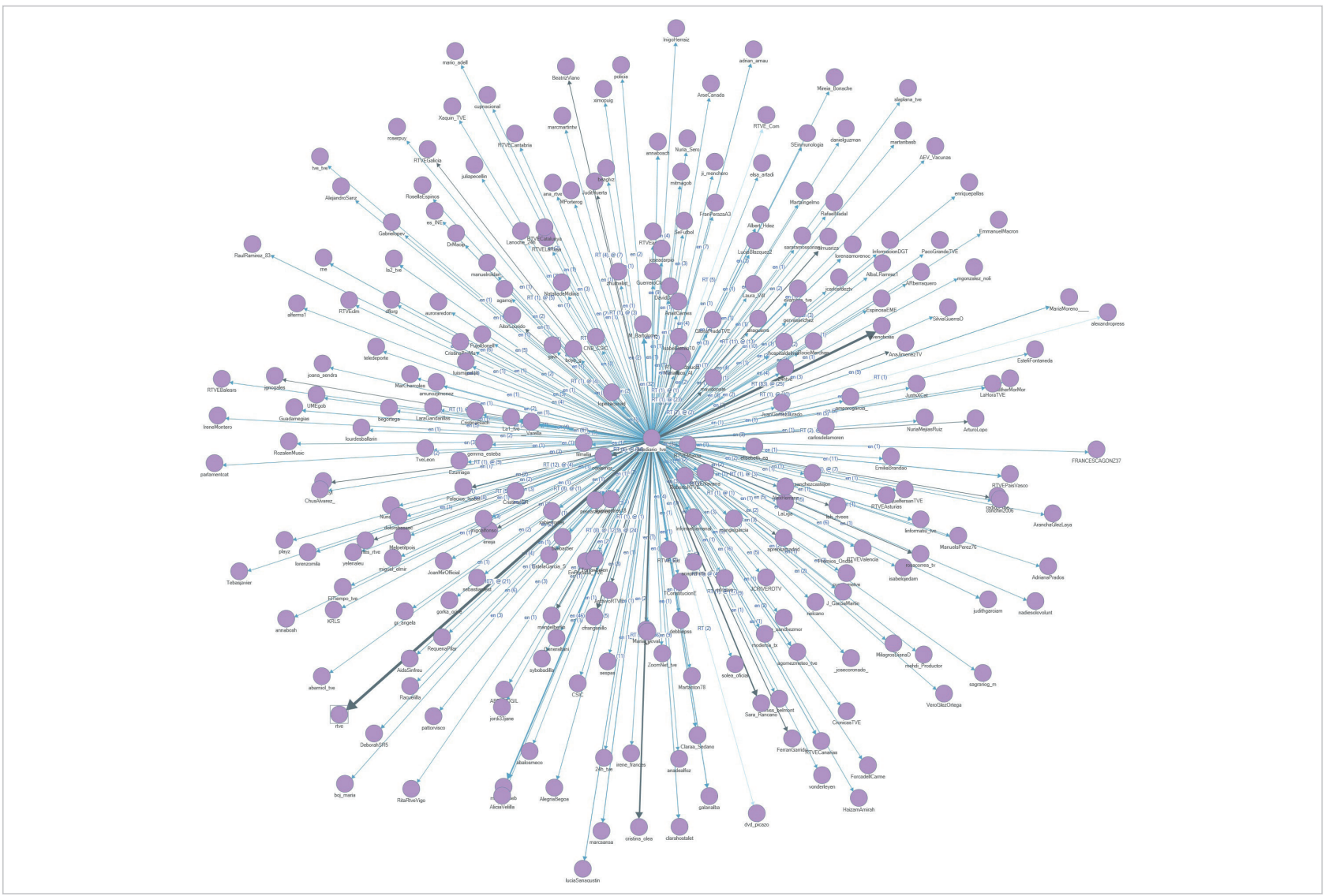

Figure 11. Retweets (RT) and comments (en) in Twitter from the @telediario_TVE account 
items and/or their own content. Likewise, as shown in Table 8, the specific media accounts were unified with the generalist accounts, as the objective was to know the number of users who interacted with the communication media in Twitter, independently if it was through the generalist account or the specific one.

As for the last subject matter, it is notable that the messages written by the Twitter users were not only centered on fundamental aspects of Brexit, such as the definitive departure of the United Kingdom from the European Union, but on more local matters, such as the effect on the bilateral relationships between Spain and Gibraltar, the situation of the Spanish truck drivers, and the border controls between France and the UK, the different economic programs that are developed within the European Union, or how the exit of the United Kingdom would affect the Spanish Football League with respect to the signing of British players.

Lastly, contents that were racist or stereotypical in character were detected associated with the exit of the United Kingdom from the European Union, especially centered on the British tourists or the legal status of Gibraltar. Nevertheless, the repercussion and interaction of the users in Twitter with respect to the Brexit news was eclipsed by other local news and events, such as the "Filomena" snow storm, or the effects of the pandemic due to Covid-19 in Spain during Christmas. With that in mind, two examples of tweets that had a great repercussion are shown below:

- LIVE \#Filomena / A 55 year old man dies from a heart attack on Sunday after he was trapped in his car due to the storm in Belltall, Tarragona https://t.co/OqYBRhMI3L https://t.co/n4YJoE4gis @el_pais 11-01-2021.

- The German company BioNTech will increase the production of the vaccine against the coronavirus to meet the needs of the UE countries, where a certain scarcity has been found https://t.co/cSk1MPMGOn @elmundoes 1-01-2021.

\section{Discussion and conclusions}

The ultimate exit of the United Kingdom from the European Union is a historical event that negatively affects the objectives of common governance and the economic, commercial, and social integration of this political community. After their 48-year membership, the United Kingdom abandoned a space that had only grown and broadened its list of member states since the signing of the foundational Treaty of Rome in 1957, until 2021. The importance of this exit foreshadowed an intense debate in the Spanish communication media and their social networks, places that were more visited and more attractive for participating in the discussion about current events. However, from the analysis of the news discourses from the Spanish media published in Twitter, two weeks before and two weeks after January $1^{\text {st }}, 2021$-the date set for Brexit- it is concluded that there was a significant lack of interest from the Spanish citizens towards a matter of national and international significance.

This attitude could be due to the 4-year period in which society was worn down by this process, since the voting on the Referendum about the permanence of the United Kingdom in the European Union took place. In this sense, the results revealed a greater interest towards the local events ('Filomena' storm, or the effect of Covid-19 on the Christmas season), due to the interest of the users, as well as media coverage, which lead to a discouraging assessment: despite the globalized scope of events facilitated by the internet and social networks, interests still remain local. Perhaps this is due to the ultimate loss of interest for news in general, or perhaps the media have not been able to transmit the deserved importance of this event
The digital native press does not at all possess accounts that especially focused on the international arena, as opposed to what we found in the all the traditional press titles that mimicked, perhaps, the different sections of the traditional newspapers 
(Larrondo-Ureta, 2006; Dader, 2020). Another reason for this lack of proactivity revolves around the mistrust generated during the months of "infodemia": since the start of the health crisis in March, 2020, the phenomenon of fake news increased the suspicion of the population towards the social networks, which leads to the loss of interest (Masip; Suau; Ruiz-Caballero, 2020; Pérez-Curiel; Velasco-Molpeceres, 2020).

In second place, the journalistic use of Twitter as a more direct and effective social network for communicating news events, due to the increased permeability with users, was confirmed. As highlighted in other research studies (Salaverría, 2019; García-Avilés et al., 2019; Newman et al., 2020; Barrios-Rubio; Pedrero-Esteban, 2021), the media industry has assumed the demands for a new digital ecosystem and had tried to adopt strategies for competing for the economy of attention, to re-invent their narratives and languages in the networks, to promote the participation of the users, and to favor the horizontal nature of communication. However, these study conclusions allow us to infer that it is the press -traditional and digital native - the ones that led the way with a greater intervention, with a total of $65.7 \%$ of the total tweets published about Brexit. We should also add, in this sense, that the audiences accessed the generic accounts more often than those specialized on international news, where interaction was barely observed.

The news reporting activity of the media in Twitter during the period analyzed not only provides proof that the journalistic brands make their presence known in these channels, but also indicated the opportunity to define their own and differential communication models to begin to recover their legitimacy and counteract the problem of the expansion of fake news and disinformation. In this sense, the study allows us to conclude that the segmentation of channels allowed by the social networks is not always advantageous with respect to impact: it was observed that despite there being a greater flow of information about Brexit in specialized channels (@abc_mundo, etc.), there was a greater degree of interaction in the main accounts, with less tweets per subject.

We can conclude, in agreement with previous works (García-Avilés et al., 2019; López-Rabadán; Mellado, 2019), that the greater the disaggregation of the distribution of the medium into different accounts, the lesser their ability to have an impact on the population. The results also showed that the digital native press does not at all possess accounts that especially focused on the international arena, as opposed to what we found in the all the traditional press titles that mimicked, perhaps, the different sections of the traditional newspapers. As previously mentioned, this strategy seems not to be useful in terms of the impact on the audience when trying to create empathy towards the European sphere, as demonstrated in studies such as those by Marquart et al. (2018) and Tuñón-Navarro, Oleart and Bouza-García (2019), who described the impact of the digital media on the perceptions of the audiences, and that authors such as Tuñón-Navarro and Carral (2019) propose as an adequate vehicle that can be used to have a political impact on the citizens. On the other hand, in the case of television stations, a smaller impact of these news items was found in the generic accounts, and a greater one in the general information-specific ones. As for the radio stations, more information was also communicated in the specific accounts, except for the COPE station, whose parent account has a greater impact and was more interested on information related to Brexit.

The truth is that the consumption of the news on social networks has become natural, especially in the younger population niche, which has intensively absorbed technological determinism and constant online connectivity (Pérez-Escoda; García-Ruiz, 2020; Pérez-Escoda et al., 2021). This is one of the main realities that justify the needs of the media to re-enforce their discourse in the networks, to legitimize their role as gatekeepers of the news events and as professional agents in the management of information, especially in Europe (Dader, 2020; Elías, 2018). The advantages provided by usability, accessibility, multimediality, and hypertextuality, reach their peak in these areas, in which the reach of the traditional media has become diluted against the creation of a model where any user can circulate content and become a source of information for others (Larrondo-Ureta; Meso-Ayerdi; Peña-Fernández, 2020).

The fact that each individual has the ability to propagate pseudo-informational content has forever altered the paradigm of communication: any user can prescribe, even though the rigor and verification demands that are intrinsic to journalism are not met (Pedrero-Esteban; Pérez-Escoda, 2021). This justifies the need for the media to re-enforce and legitimize their presence in the networks, which along with politics, have been shown to be the main roads towards misinformation in Europe (García-Vivero; López-García, 2021). If democracies are founded on discussion and debate about the divergences in the same reality, how should we face the divergences found between the different "realities" that are observed in social networks? How should the media meet their responsibilities in a scenario whose logic does not rest on attributes of truth, but instead of virality? How should their demand for information coverage be applied for processes that are greatly exposed to political and social controversy such

If democracies are founded on discussion and debate about the divergences in the same reality, how should we face the divergences found between the different "realities" that are observed in social networks? How should the media meet their responsibilities in a scenario whose logic does not rest on attributes of truth, but instead of virality? 
In this sense, the study opens future lines of research for completing this analysis, which places the responsibility on the media for offering journalism adapted to the new environments: the social networks. These spaces could be "journalism's best ally or worst enemy", as stated by journalists who are experts on the subject (Ríos, 2017), or scholars who propose social networks as a solution to communication problems, specifically in the chaos of the European space (Marquart et al., 2018; Tuñón-Navarro; Carral, 2019), which has started to break apart, as pointed out by Alonso-Muñoz and Casero-Ripollés (2020), with anti-European sentiments that are precisely nested in social networks. For this, however, there is an urgent need, on the one hand, for an adequate journalistic discourse, and on the other, for an increase in the legitimacy of the media to regain the trust of the audiences and to foster democratic participation.

\section{Notes}

1. The metadata obtained from each tweet are the following: tweet ID; User name; Tweet; post time; type of tweet (retweet or tweet); by whom it was retweeted; number of retweets; tags or hashtags that the tweet has; mentions to the account that has sent it; name of the user who posted the tweet; user location; user website; user biography; number of accounts that follow the user; number of profiles that the user follows and, finally, coordinates from which the tweet is sent. QSR Nvivo's own software has an extension for the Google Chrome browser called NCapture that allows, through the use of the Twitter API, the capture of tweets, both from different public accounts and hashtags without the need to use other systems based on $R$ or in Python. In this exploratory research, the extraction of tweets was carried out through this tool exclusively from the 42 profiles on Twitter listed in Table 3.

2. Although it is important to point out that the United Kingdom left the EU on January 30, 2020 when the Withdrawal Agreement was ratified. What happened on December 31 was that the trade and cooperation agreement came into force, assuming the de facto exit in all aspects.

3. Retweets from the official accounts of the selected media have not been taken into account, but only the original messages sent.

4. Some media have a bilingual edition that is not only in Spanish, as is the case with El periódico de Catalunya, which is also published in other co-official languages of Spain. Only the editions written in Spanish were selected for this study.

5. Although the general agreement between the European Union and the United Kingdom was closed on December 24 , the status of Gibraltar and its relationship -mainly- with Spain was one of the last issues to be defined (December 30), and as it was relevant information for Spanish interests, most of the media were waiting for news on this issue.

6. Users / fans with a lower level of interaction were ignored, such as lurkers (Establés, 2020; Establés; Guerrero-Picó; Contreras-Espinosa, 2019). With the data obtained, it was not possible to identify who were mere observers who did not produce any type of interaction, not even the most basic (give a "like" or "retweet" messages).

7. There is a clear strategy on the part of some media and / or journalists to spread the messages broadcasted on the Twitter profiles of media outlets that are part of the same group: Vocento, Unidad Editorial, Atresmedia, RTVE, etc.

\section{References}

AIMC (2020). Resumen general de resultados EGM. Tercera ola del año 2020. Asociación para la Investigación de Medios de Comunicación.

https://reporting.aimc.es/index.htm/\#/main/cockpit

AIMC (2021). Marco general de los medios en España 2021. Asociación para la Investigación de Medios de Comunicación. https://www.aimc.es/a1mc-cOnt3nt/uploads/2021/02/marco2021.pdf

Alonso-Muñoz, Laura; Casero-Ripollés, Andreu (2020). “Populism against Europe in social media: The Eurosceptic discourse on Twitter in Spain, Italy, France, and United Kingdom during the campaign of the 2019 European Parliament election". Frontiers in communication, n. 5.

https://doi.org/10.3389/fcomm.2020.00054

Arcila-Calderón, Carlos; Barbosa-Caro, Eduar; Cabezuelo-Lorenzo, Francisco (2016). "Técnicas big data: análisis de textos a gran escala para la investigación científica y periodística". El profesional de la información, v. 25, n. 4, pp. 623-631. https://doi.org/10.3145/epi.2016.jul.12

Barlovento (2021). Análisis de la industria televisiva-audiovisual 2020. Barlovento comunicación. https://www.barloventocomunicacion.es/wp-content/uploads/2020/01/analisis-de-la-industria-televisiva-audiovisual2020-Barlovento-1.pdf

Barnard, Stephen R. (2014). "Tweet or be sacked': Twitter and the new elements of journalistic practice". Journalism, v. 17 , n. 2, pp. 190-207.

https://doi.org/10.1177/1464884914553079

Barrios-Rubio, Andrés; Pedrero-Esteban, Luis-Miguel (2021). "The transformation of the Colombian media industry in the smartphone era". Journal of creative communications, v. 16, n. 1, pp. 45-60.

https://doi.org/10.1177/0973258620981347 
Bastos, Marco; Mercea, Dan (2018). "The public accountability of social platforms: Lessons from a study on bots and trolls in the Brexit campaign". Philosophical transactions of the Royal Society A: mathematical, physical, and engineering sciences, v. 376, n. 2128.

https://doi.org/10.1098/rsta.2018.0003

Bauman, Zygmunt; Leoncini, Thomas (2018). Generación líquida: Transformaciones en la era 3.0. México: Paidós. ISBN: 9786077474890

Brems, Cara; Temmerman, Martina; Graham, Todd; Broersma, Marcel (2017). "Personal branding on Twitter: How employed and freelance journalists stage themselves on social media". Digital journalism, v. 5, n. 4, pp. 443-459.

https://doi.org/10.1080/21670811.2016.1176534

Brennen, J. Scott; Simon, Felix; Howard, Philip N.; Nielsen, Rasmus-Kleis (2020). Types, sources, and claims of Covid-19 misinformation. Oxford: Reuters institute for the study of journalism.

https://reutersinstitute.politics.ox.ac.uk/types-sources-and-claims-covid-19-misinformation

British Council (2020). Origen y evolución de la palabra "Brexit".

https://www.britishcouncil.es/sobre-nosotros/prensa/origen-evolucion-palabra-brexit

Busón-Buesa, Carlos (2020). "La minería de opinión para el análisis del discurso de odio en las redes sociales". Commons: revista de comunicación y ciudadanía digital, v. 9, n. 1, pp. 119-159.

https://dialnet.unirioja.es/servlet/articulo?codigo $=7497483$

Casero-Ripollés, Andreu (2020). "Impacto del Covid-19 en el sistema de medios. Consecuencias comunicativas y democráticas del consumo de noticias durante el brote". El profesional de la información, v. 29, n. 2, e290223.

https://doi.org/10.3145/epi.2020.mar.23

Casero-Ripollés, Andreu; García-Gordillo, Mar (2020). "La influencia del periodismo en el ecosistema digital”. En: Pedrero-Esteban, Luis-Miguel; Pérez-Escoda, Ana (coords.). Cartografía de la comunicación postdigital. Medios y audiencias en la sociedad de la Covid-19. Aranzadi-Thomson Reuters, pp. 157-175. ISBN: 9788413458250

CIS (2020). “Fusión de barómetros de septiembre a diciembre de 2020. Estudio n. 66091220”. Centro de Investigaciones Sociológicas.

http://www.cis.es/cis/export/sites/default/-Archivos/Marginales/Globales/66091220/es66091220mar.pdf

Clarke, Harold D.; Goodwin, Matthew; Whiteley, Paul (2017). Brexit: Why Britain voted to leave the European Union. Cambridge University Press. ISBN: 9781316605042

Comisión Europea (2018). Comunicación de la Comisión al Parlamento Europeo, al Consejo, al Comité Económico y Social Europeo y al Comité de las Regiones, sobre la lucha de la desinformación en línea: un enfoque europeo. COM/2018/236 final.

https://eur-lex.europa.eu/legal-content/es/TXT/?uri=CELEX\%3A52018DC0236

Coromina, Òscar; Padilla, Adrián (2018). "Análisis de las desinformaciones del referéndum del 1 de octubre detectadas por Maldito Bulo". Quaderns del CAC, v. 21, n. 44, pp. 17-26.

https://www.cac.cat/sites/default/files/2018-08/Q44_ES.pdf

Dader, José-Luis (2020). “Ciberpolítica y ciberdemocracia: Nuevas herramientas y viejos desafíos para la comunicación política". En: Castromil, Antón R.; Humanes, María-Luisa; García-Tójar, Luis (eds.). La comunicación política en la era de la mediatización. Salamanca: Comunicación social. ISBN: 9788417600327

Elías, Carlos (2018). “Fakenews, poder y periodismo en la era de la posverdad y 'hechos alternativos'”. Revista ámbitos, n. 40. https://institucionales.us.es/ambitos/fakenews-poder-y-periodismo-en-la-era-de-la-posverdad-y-hechos-alternativos

Establés, María-José (2020). Entre profesionales y aficionados: Relaciones y tensiones entre fans e industrias culturales, procesos y estrategias de trabajo y creación. Estudios de caso de los fandoms castellanoparlantes de Doctor Who y EI ministerio del tiempo. Tesis doctoral, Universitat Pompeu Fabra.

http://hdl.handle.net/10803/669211

Establés, María-José; Guerrero-Pico, Mar; Contreras-Espinosa, Ruth S. (2019). “Jugadores, escritores e influencers en redes sociales: procesos de profesionalización entre adolescentes". Revista latina de comunicación social, v. 74, pp. $214-236$. https://doi.org/10.4185/RLCS-2019-1328

European Commission (2020). “Standard Eurobarometer 93. Summer 2020”. data.europa.eu. https://data.europa.eu/data/datasets/s2262_93_1_93_1_eng

García-Avilés, José-Alberto; Carvajal-Prieto, Miguel; Arias-Robles, Félix; De-Lara-González, Alicia (2019). “Journalists' views on innovating in the newsroom: proposing a model of the diffusion on innovations in media outlets". Journal of media innovation, v. 5, n. 1.

https://doi.org/10.5617/jomi.v5i1.3968 
García-Vivero, Gloria; López-García, Xosé (2021). “La verificación de datos en Europa. Análisis de 5 iniciativas europeas: Maldita.es, Newtral, Pagella politica, Les décodeurs y BBC reality check". AdComunica, n. 21, pp. 235-264. https://doi.org/10.6035/2174-0992.2021.21.12

Haman, Michael; Školník, Milan (2021). "Politicians on social media. The online database of members of national parliaments on Twitter". Profesional de la información, v. 30, n. 2, e300217.

https://doi.org/10.3145/epi.2021.mar.17

Hermida, Alfred (2012). "Tweets and truth: Journalism as a discipline of collaborative verification". Journalism practice, v. 6, n. 5-6, pp. 659-668.

https://doi.org/10.1080/17512786.2012.667269

Krzyżanowski, Michal (2019). “Brexit and the imaginary of 'crisis': A discourse conceptual analysis of European news media". Critical discourse studies, v. 16, n. 4, pp. 465-490.

https://doi.org/10.1080/17405904.2019.1592001

Larrondo-Ureta, Ainara (2006). "Del impacto mediático al olvido: la pérdida de interés noticioso como indicador de la deshumanización de los medios". Revista latina de comunicación social, v. 9, n. 61.

https://www.redalyc.org/articulo.oa?id=81996112

Larrondo-Ureta, Ainara; Meso-Ayerdi, Koldobika; Peña-Fernández, Simón (2020). "Shared spaces for news content production in Spanish online media". In: Vázquez-Herrero, Jorge; Direito-Rebollal, Sabela; Silva-Rodríguez, Alba; López-García, Xosé (eds.). Journalistic metamorphosis: media transformation in the digital age. Springer, pp. 113-127. ISBN: 978 3 030363147

Larrondo-Ureta, Ainara; Peña-Fernández, Simón; Meso-Ayerdi, Koldobika (coords.) (2020). Periodismo hiperconectado. Claves para la profesión en un contexto de retos y oportunidades. Bilbao: Universidad del País Vasco. ISBN: 97884 13191591

https://addi.ehu.es/handle/10810/43930

López-Rabadán, Pablo; Mellado, Claudia (2019). "Twitter as a space for interaction in political journalism. Dynamics, consequences and proposal of interactivity scale for social media". Communication and society, v. 32, n. 1, pp. 1-18. https://doi.org/10.15581/003.32.1.1-18

Marcos-García, Silvia; Alonso-Muñoz, Laura; López-Meri, Amparo (2021). "Periodismo y nuevas narrativas. Storytelling como formato de difusión informativa en redes sociales". Estudios sobre el mensaje periodístico, v. 27, n. 2, pp. 553-567. https://doi.org/10.5209/esmp. 71193

Marín-Dueñas, Pedro-Pablo; Simancas-González, Esther; Berzosa-Moreno, Alba (2019). "Uso e influencia de Twitter en la comunicación política: el caso del Partido Popular y Podemos en las elecciones generales de 2016". Cuadernos info, n. 45, pp. 129-144.

https://doi.org/10.7764/cdi.45.1595

Marquart, Franziska; Goldberg, Andreas C.; Van-Elsas, Erika J.; Brosius, Anna; De-Vreese, Claes H. (2019). “Knowing is not loving: media effects on knowledge about and attitudes toward the EU". Journal of European integration, v. 41, n. 5, pp. 641-655.

https://doi.org/10.1080/07036337.2018.1546302

Masip, Pere; Suau, Jaume; Ruiz-Caballero, Carlos (2020). “Percepciones sobre medios de comunicación y desinformación: ideología y polarización en el sistema mediático español”. Profesional de la información, v. 29, n. 5, e290527. https://doi.org/10.3145/epi.2020.sep.27

Mayo-Cubero, Marcos (2020). "News sections, journalists and information sources in the journalistic coverage of crises and emergencies in Spain". El profesional de la información, v. 29, n. 2, e290211.

https://doi.org/10.3145/epi.2020.mar.11

Newman, Nic; Fletcher, Richard; Schulz, Anne; Andi, Simge; Nielsen, Rasmus-Kleis (2020). Digital news report 2020. Reuters Institute, University of Oxford. https://reutersinstitute.politics.ox.ac.uk/sites/default/files/2020-06/DNR_2020_FINAL.pdf

Pedrero-Esteban, Luis-Miguel; Pérez-Escoda, Ana (2021). “Democracia y digitalización: implicaciones éticas de la IA en la personalización de contenidos a través de interfaces de voz". Recerca. Revista de pensament i anàlisi, v. 26, n. 2. https://doi.org/10.6035/recerca.4666

Pérez-Curiel, Concha; Velasco-Molpeceres, Ana-María (2020). "Impacto del discurso político en la difusión de bulos sobre Covid-19. Influencia de la desinformación en públicos y medios". Revista latina de comunicación social, v. 78, pp. 65-97.

https://doi.org/10.4185/rlcs-2020-1469 
Pérez-Escoda, Ana; García-Ruiz, Rosa (2020). “Comunicación y educación en un mundo digital y conectado". Icono 14, v. 18, n. 2.

https://doi.org/10.7195/ri14.v18i2.1580

Pérez-Escoda, Ana; Pedrero-Esteban, Luis-Miguel; Rubio-Romero, Juana; Jiménez-Narros, Carlos (2021). "Fake news reaching young people on social networks: Distrust challenging media literacy". Publications, v. 9, n. 2. https://doi.org/10.3390/publications9020024

Pérez-Tornero, José-Manuel (2020). La gran mediatización. El tsunami que expropia nuestras vidas. Barcelona: UOC Press. ISBN: 9788491807414

Ríos, Carmela (2017). "Redes sociales: el mejor aliado y el mayor enemigo del periodismo". Cuadernos de periodistas, n. 34, pp. 85-91.

https://www.cuadernosdeperiodistas.com/redes-sociales-mejor-aliado-mayor-enemigo-del-periodismo

Salaverría, Ramón (2019). “Digital journalism: 25 years of research. Review article”. El profesional de la información, v. 28, n. 1, e280101.

https://doi.org/10.3145/epi.2019.ene.01

Tuñón-Navarro, Jorge; Carral, Uxía (2019). “Twitter como solución a la comunicación europea. Análisis comparado en Alemania, Reino Unido y España". Revista latina de comunicación social, n. 74, pp. 1219-1234. https://doi.org/10.4185/RLCS-2019-1380

Tuñón-Navarro, Jorge; Oleart, Álvaro; Bouza-García, Luis (2019). “Actores europeos y desinformación: la disputa entre el factchecking, las agendas alternativas y la geopolítica". Revista de comunicación, v. 18, n. 2, pp. $245-260$. https://doi.org/10.26441/RC18.2-2019-A12

Van-Dijck, José (2016). La cultura de la conectividad. Una historia crítica de las redes sociales. Siglo XXI Editores. ISBN: 9789876296694

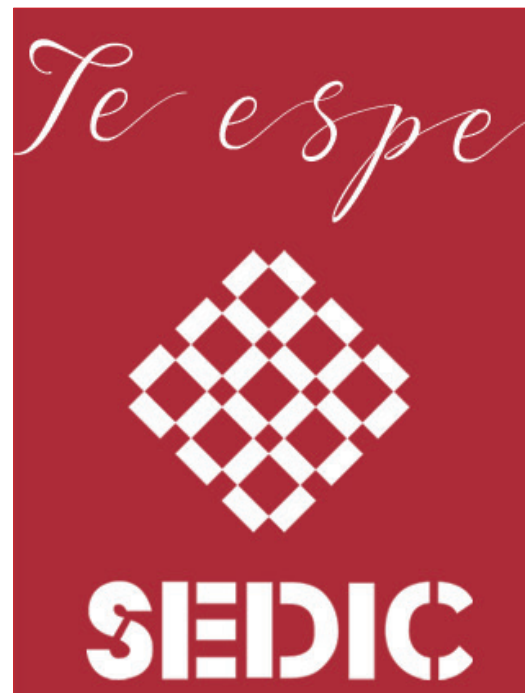

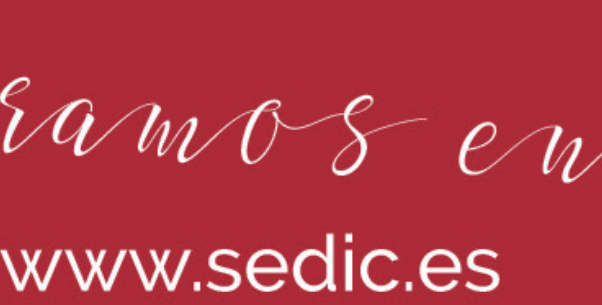

c/Rodriguez San Pedro 2,

oficina 606. 28015 Madrid

Tfno: +34915934059

secretaria@sedic.es
Sociedad

Española de

Documentación e Información

Científica

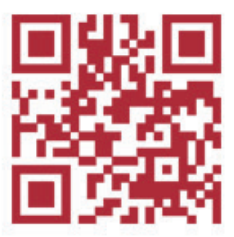

https://twitter.com/SEDIC20

f https://wwww.facebook.com/AsociacionSEDIC

in https://www.linkedin.com/groups?home=\&gid=5060038 